Utah State University

DigitalCommons@USU

1976

\title{
Utilization of Additional Species and Populations of Leafcutter Bees for Alfalfa Pollination
}

Frank D. Parker

Utah State University

P. F. Torchio

Utah State University

William P. Nye

Utah State University

M. Pedersen

Follow this and additional works at: https://digitalcommons.usu.edu/piru_pubs

Part of the Entomology Commons

\section{Recommended Citation}

Parker, F. D., P. F. Torchio, W. P. Nye, and M. Pedersen. 1976. Utilization of Additional Species and Populations of Leafcutter Bees for Alfalfa Pollination. J. of Apicult. Res. 15(2):89-92.

This Article is brought to you for free and open access by the Pollinating Insects Research Unit at DigitalCommons@USU. It has been accepted for inclusion in All PIRU Publications by an authorized administrator of DigitalCommons@USU. For more information, please contact digitalcommons@usu.edu.

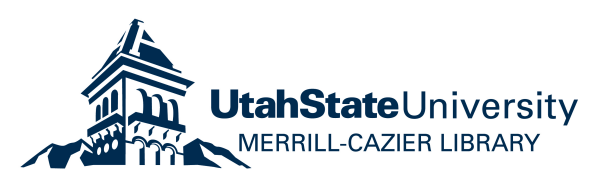


Fournal of Apicultural Research 15(2) : 89-92 (1976)

\title{
UTILIZATION OF ADDITIONAL SPECIES AND POPULATIONS OF LEAFCUTTER BEES FOR ALFALFA POLLINATION
}

\author{
F. D. Parker, P. F. Torchio, W. P. Nye and M. Pedersen * \\ Agricultural Research Service, USDA, \\ Utah State University, Logan, UT 84322, USA
}

Manuscript received for publication 6 April 1976

\section{Summary}

The introduction and establishment in the United States of species of Eutricharaea (an Old World subgenus of Megachile) are reviewed. A comparison was made by field-cage studies of American and Spanish populations of $M$. pacifica and an American population of $M$. concinna. Significant differences included the following. Spanish pacifica showed the lowest mortality in immature stages $(9 \%)$. M. concinna built about 4 times as many cells as the other bees, and was the most successful in rearing second-generation adults; seed production was also highest in the M. concinna cages. It is important on economic grounds that the possibilities of rearing other alfalfa pollinators than $M$. pacifica should be explored further.

\section{Introduction}

The leafcutter bee commonly used for alfalfa pollination in the United States (M. pacifica (Panzer)) is a species of the subgenus Eutricharaea. Although this subgenus was formerly distributed only on the continents of the Eastern Hemisphere, several species of Eutricharaea have become established in the Western Hemisphere as a result of modern commerce (Michener, 1965). The first record of Eutricharaea in the New World is that for the pale leafcutter bee, M. concinna Smith, in 1879 from Jamaica. Smith described the species as new, but it is an African species, probably introduced there during the slave trade (Pasteels, 1973); its present distribution includes the United States. Then during the first half of the present century, three other species were unintentionally introduced into the United States; $M$. pacifica (first thought to be $M$. rotundata (Fab.)), M. apicalis Spinola, and $M$. "argentata" of Authors (Hurd, 1954). The present distribution of these species in the United States is unknown, although all but $M$. apicalis are present in the alfalfa seed-growing regions of the western states.

The subgenus Eutricharaea contains well over 100 species; the exact number is unknown, since there is no world-wide list. Also, many species have not been adequately described or distinguished from known species. For example, in the Australian and South Pacific areas there are 66 species assigned to this subgenus, and in Eurasia and Africa there may be twice that number. In view of this large assemblage, the Bee Biology and Systematics Laboratory sought to identify additional alfalfa pollinators among exotic or already introduced species, hoping that some might be adaptable to specific climatic regions, or prove easy to manage in commercial rearing.

Prospects and problems of introducing foreign pollinators have been discussed by Bohart (1962). During 1974, P. F. Torchio surveyed alfalfa pollinators in Spain and set out traps to secure material for further testing. Five species of Eutricharaea were obtained, the most common being $M$. pacifica. In addition, we began our efforts to locate and

$\star$ First three authors at Bee Biology and Systematics Laboratory; M. Pedersen at Crops Research Laboratory. 
commercialize other leafcutter bee species by making a study of $M$. concinna, which is commonly found in the warm southern tier of states. Our hope was to find a species other than $M$. pacifica that could be used for alfalfa pollination in the warmer regions of our south-western states, where the mortality of the immature stages of $M$. pacifica makes successful management impractical. Other problems associated with $M$. pacifica are its multi-generations, unexplained larval loss, high male sex ratio, low tripping rate of alfalfa flowers (compared with other known alfalfa pollinators), and the wide range of plants visited for nectar and pollen.

Little research has been done to determine whether $M$. pacifica, the most common of the accidentally introduced species, is the most desirable alfalfa pollinator, though a multimillion dollar industry is centred around the management of this bee (Bohart, 1971, 1972). Also, little effort has been made to utilize other populations or species; Bulter and Wargo (1963) studied M. concinna in Arizona, and Johansen and Eves (1970) found that $M$. concinna (with its peak emergence in mid-season) could supplement $M$. pacifica as a pollinator in Washington State. Natural populations of this bee have, however, not increased to become a significant addition to alfalfa pollinators.

By 1975 the progress towards our two goals encouraged us to conduct a field test on caged alfalfa, to compare the nesting activities, manageability, and production of alfalfa seed, by American and Spanish populations of $M$. pacifica and by M. concinna .

\section{Materials and Methods}

The Spanish population of $M$. pacifica was obtained from trap nests placed near Valladolid; the American population was obtained from our laboratory field colony. The $M$. concinna population came from our greenhouse colony (obtained from Arizona the previous season) and trap nests set out in Arizona by P. F. Torchio. The nest contents of each population and species were isolated in gelatin capsules and held in cold storage $\left(3^{\circ} \mathrm{C}\right)$ during the winter of $1974-75$. About 20 days before alfalfa bloom, the larvae were incubated at $29^{\circ}$; because of the lateness of the 1975 field season, bees were not incubated until mid-June.

The cages used for the tests were $6 \times 6 \times 2 \mathrm{~m}$ and covered with saran cloth, $14 \times 18$ mesh per linear inch $(25 \mathrm{~mm})$; they were set up over a stand 2 years old of high saponin Ranger alfalfa (Parker \& Pedersen, 1974). No insecticides were applied before the bees were introduced. The nesting unit for each cage was hung in the NW corner with the open end facing SE. About midway through the test, a second unit was hung in the SE corner of each cage with the open end facing NW. These units were made by taping together about 22 moulded polystyrene wafers (Beaver Plastics Ltd.) and gluing them into cardboard containers. The units were coated on the outside with polyurethane to protect against rain.

Bees were released in the cages daily from 7 July until 17 July; numbers released each day were dependent on the rate of emergence from the cells in the incubator. However, a total of 100 males and 100 females were released in each cage; and there were 4 cages of each population or species, a total of 12 cages. During the second week of August, the nest boxes were removed from the cages, and the cages were sprayed with an insecticide. Then the nest boxes were opened, and the cell series removed and placed in large petri dishes. The dishes were held at $20^{\circ}$ for 6 weeks so that we could determine the number of second-generation adults that emerged. After emergence had ceased, the cells were dissected and the contents recorded. Seed production in each cage was determined after the alfalfa seed matured. First the cages were removed; then the plants were cut and windrowed; finally the seed was thrashed and cleaned by machine. 


\section{Results}

Significant differences were noted in the nesting habits of the populations and species. As in an experiment conducted the previous season (unpublished), $M$. concinna produced nearly four times as many cells as $M$. pacifica, but the two populations of $M$. pacifica produced similar numbers (Table 1). The percentage of nests capped also varied; $63 \%$ in units containing $M$. concinna, 30\% and $9 \%$ in units containing Spanish and American $M$. pacifica, respectively. The pattern of nesting within the nest unit varied too. The Spanish bees nested in the top five rows of holes, and only a few nests were scattered along the vertical midline. Nests of the American population were more widely distributed, but they were concentrated along the bottom half of the unit. Nests of $M$. concinna were more concentrated along the bottom half, but extended up the sides and midline of some units.

The three populations differed significantly in the mortality rate of immature stages (Table 1). The rate for the American population of $M$. pacifica was higher than that recorded in previous years in similar circumstances (Parker \& Pedersen, 1974), but it was consistent with the average loss for commercial installations in Idaho and eastern Oregon (50\% in 1975, R. Bitner, Pollination Consultant, personal communication). Most deaths in all three populations occurred in the second and third instars.

Significant differences in voltinism were noted. More second-generation adults emerged from the American than from the Spanish population of $M$. pacifica, and more from $M$. concinna than from $M$. pacifica (Table 1 ).

Significantly more seed was produced in cages containing $M$. concinna than in cages containing $M$. pacifica (Table 1).

TABLE 1. Average number of cells produced, and the mortality of immature stages, for American and Spanish populations of Megachile pacifica, and a population of $M$. concinna, caged on alfalfa plots. The last column gives the average seed production in the cage. Four replications, Logan, Utah, 1975.

\begin{tabular}{lcccc}
\hline \multicolumn{1}{c}{ Species } & $\begin{array}{c}\text { Mortality } \\
\text { of immature } \\
\text { stages }(\%)\end{array}$ & $\begin{array}{c}\text { Emergence of } 2 \text { 2nd } \\
\text { generation adults } \\
(\% \text { of larvae })\end{array}$ & $\begin{array}{c}\text { No. } \\
\text { cells/cage }\end{array}$ & $\begin{array}{c}W t . \\
\text { seed/cage }(g)\end{array}$ \\
\hline American pacifica & 52 & 34 & 146 & 465 \\
Spanish pacifica & 9 & 7 & 184 & 313 \\
American concinna & 28 & 72 & 662 & 670 \\
Mean LSD $(\mathrm{P}<0 \cdot 05)$ & 15 & 26 & 192 & 143 \\
\hline
\end{tabular}

Cages containing Spanish $M$. pacifica produced less seed than cages containing the American population, but half the plants caged with the Spanish bees produced as much seed as those caged with the American bees.

\section{Discussion}

Our present study suggests that $M$. pacifica populations in the Old World may have characters that could be beneficial to the alfalfa seed industry in USA. For example, seed growers in many areas need a univoltine species because of the discontinuity of flowering crops, especially late in the season. Also, there is a need to reduce the high loss of bees during the immature stages. If the mortality rate of the Spanish population, and the percentage of these bees that remain in diapause, are consistently low, as our results indicate, then these bees could be beneficial and highly desirable to the seed industry.

Our studies revealed distinct differences in nesting ability. Megachile concinna construc- 
ted far more cells than $M$. pacifica. (This difference may arise from the rapid flight of $M$. concinna, which enables it to visit many more flowers per minute.) An increase in the rate of reproduction of colonies of pollinators would greatly benefit seed growers. At present, many growers must augment most of their bee stocks annually. Our studies indicate that benefits might indeed be derived if additional populations and species could be located among the estimated 140 species of Eutricharaea extant in the Old World. If, among additional species discovered in this way, populations of leafcutter bees are identified that can be used commercially in the areas of the Midwest and the hotter south-western seed-producing regions that now lack adequate pollinators, an increase in seed production would seem inevitable. Also, many countries in Europe have in the past imported $M$. pacifica from the United States instead of exploring the possibilities of their native species (which in most countries include $M$. pacifica). Therefore, research similar to ours has been or is in the process of being conducted in several countries of Europe and Asia, including Denmark (Holm, 1964, 1972), Iran (Tirgari, 1967, 1969), France, (Tasei, 1975), Egypt (Ibrahim, 1974) and Poland (Ruszkowski, 1975). Recent studies conducted in Egypt and Poland indicate that each country has an efficient alfalfa leafcutter bee pollinator other than $M$. pacifica.

\section{Acknowledgements}

Appreciation is extended to the California Alfalfa Seed Research Board and the Field Seed Institute of North America for financial assistance. Dr. E. Asensio, Departmento de Plantas de Gran Gultivo, Valladolid, Spain, assisted in placement of trap nests in the field, and also in gathering and shipping materials to the United States. D. Cheney and H. Potter of the Bee Biology and Systematics Laboratory, Logan, Utah, assisted in conducting the experiments. Appreciation is also extended to Drs. G. E. Bohart, C. A. Johansen, J. Undurraga and N. D. Waters, who reviewed the manuscript.

\section{References}

Bohart, G. E. (1962) Introduction of foreign pollinators, prospects and problems. Medd. Sverig. Froodlorb. (7): 181-188

Bulter, G. E. \& Wargo, M. J. (1963) Biological notes on Megachile concinna Smith in Arizona. Pan.-Pacif. Ent. 39: 201-206

Holm, S. N. (1964) Bladskaerbien (Megachile rotundata). En "ny" bi til bestøvning af planter i drivhus? Ugeskr. Landm. 109(45/46): 719-721

- - (1972) Studies on trapping, nesting, and rearing of some Megachile species and on their parasites in Denmark. Ent. scand. 3: 169-180

Hurd, P. D. (1954) Distributional notes on Eutricharaea, a Palearctic subgenus of Megachile, which has become established in the United States. Ent. News 65: 93-95

IBRAHIM, M. M. (1974) Breeding and propagation of some efficient insect pollinators in newly reclaimed land in Egypt. Bee Biology and Systematics Laboratory, Logan, Utah: Project F4-ENT-15, Res. Rep. No. 7, unpublished

Johansen, C. A. \& Eves, J. (1970) Bee Research Investigations, 1970. Pullman, Wash.: Washington State University

Michener, C. D. (1965) A classification of the bees of the Australian and South Pacific regions. Bull. Am. Mus. nat. Hist. No. 130

Parker, F. D. \& Pedersen, M. W. (1974) Alfalfa leafcutter bee: Effect of alfalfa saponins on larval mortality. Envir. Ent. 4: 103-104

Pasteels, J. J. (1973) Espèces nouvelles de Megachilidae d'Afrique Noire. Revue Zool. Bot. afr. $87: 697-727$

Ruszkowski, A. (1974) The search for the methods to increase populations of insects pollinating alfalfa. Bee Biology and Systematics Laboratory, Logan, Utah: Project PL-ARS-42, 1st A. Rep., unpublished

Tasei, J. G. (1975) Le problème de l'adaptation de Megachile (Eutricharaea) pacifica Panzer américain en France. Apidologie 6(1): 1-57

TIRgARI, S. (1967) Investigations of forage legume crop pollinators in Iran: Studies on the biology and propagation of Anthidium sp. and Megachile sp. Prog. Rep. Ahwaz Agric. Coll. (1969) Exchange and introduction of alfalfa bee pollinators between Iran and the United States and the biology of these bees. 2nd Natn. Congr. Ent. \& Pest Control, Iran 